\title{
PENINGKATAN KEMAMPUAN SELF-REGULATED LEARNING (SRL) SISWA SEKOLAH DASAR MELALUI MODEL PEMBELAJARAN KOOPERATIF TIPE THINK PAIR SHARE (TPS)
}

\author{
Dede Salim Nahdi ${ }^{1}$ ) dan Juju \\ Email : an_nahdi@yahoo.co.id
}

\begin{abstract}
ABSRTAK
Penelitian ini dilatarbelakangi oleh rendahnya self-regulated learning siswa sekolah dasar. Peneliti memberikan solusi model pembelajaran kooperatif tipe think pair share untuk meningkatkan kemampuan tersebut. Penelitian ini berbentuk kuasi eksperimen mengambil populasi siswa sekolah dasar kelas IV dibawah UPTD Pendidikan kecamatan Cingambul kabupaten Majalengka dengan sampel 2 kelas yaitu pada Sekolah Dasar Negeri Cingambul 4 dan Cingambul 5. Dari dua kelas yang dipilih dalam penelitian ini, salah satunya digunakan sebagai kelas eksperimen yang memperoleh pembelajaran dengan pembelajaran kooperatif tipe think pair share, sedangkan kelas lainnnya sebagai kelas kontrol yang pembelajarannya menggunakan pembelajaran konvensional. Kedua kelompok diberikan pretes skala dan postes skala kemampuan self-regulated learning. Data pretes skala dan postes skala self-regulated learning yang diperoleh diuji secara kuantitatif dengan uji perbedaan rerata parametrik uji- $t$ dan nonparametrik Mann-Whitney. Hasil penelitian menunjukkan bahwa peningkatan kemampuan self-regulated learning siswa yang mendapat pembelajaran dengan menggunakan pembelajaran kooperatif tipe think pair share lebih baik daripada siswa yang menggunakan pembelajarannya konvensional.
\end{abstract}

Kata kunci : pembelajaran kooperatif tipe think pair share, self-regulated learning

\footnotetext{
${ }^{1}$ Penulis adalah dosen tetap Prodi PGSD Fakultas Pendidikan Dasar dan Menengah Universitas Majalengka
} 


\section{Pendahuluan}

Sumber daya manusia yang berkualitas pada saat ini sangat diperlukan bagi negara berkembang, termasuk Indonesia. Hal ini erat kaitannya dengan globalisasi dunia yang dimasuki oleh Indonesia pada saat ini. Kualitas kehidupan berbangsa ditentukan ditentukan oleh faktor pendidikan. Pendidikan memiliki posisi penting untuk menciptakan kehidupan bangsa yang cerdas, damai, terbuka, dan demokratis. Pembaharuan pendidikan harus dilakukan untuk meningkatkan kualitas pendidikan nasional, Nurhadi (2003: 1). Masyarakat semakin menyadari akan pentingnya pendidikan untuk bersaing meraih kesempatan yang lebih baik pada berbagai bidang.

Pendidikan kita seringkali hanya
sebatas transfer ilmu dan tidak membangun karakter anak didik. Siswa tidak diberi kesempatan untuk merefleksikan dan memposisikan dirinya dalam sistem pendidikan yang sematamata untuk kepentingan dunia kerja. Pendidikan kita seringkali hanya berupa transfer ilmu berdasarkan kompetensi yang tidak mengarah pada pembentukan karakter dan masih berbasis disiplin ilmu. Untuk membekali pengetahuan, ketrampilan, nilai dan sikap, serta kemampuan berfikir kritis dan kreatif dalam rangka mengambil keputusan, dibutuhkan program pendidikan IPS (social studies).

Tujuan pendidikan IPS (social studies) tidak dapat lepas dari tujuan pendidikan nasional yang tercantum dalam SISDIKNAS (2003: 2) bahwa tujuan pendidikan nasional adalah terwujudnya mas yarakat Indonesia yang damai, demokratis, berakhlak, berkeahlian, berdaya saing, maju dan sejahtera dalam wadah kesatuan Negara Kesatuan Republik Indonesia yang didukung oleh manusia Indonesia yang sehat, mandiri, beriman, bertakwa, berakhlak mulia, cinta tanah air, berdasarkan hukum dan lingkungan, menguasai ilmu pengetahuan dan teknologi, memiliki etos kerja serta disiplin.

Melalui pendidikan IPS di sekolah diharapkan dapat membekali pengetahuan dan wawasan tentang konsep dasar ilmu sosial dan humaniora, memiliki kepekaan dan kesadaran terhadap masalah sosial di lingkungannnya serta mampu memecahkan masalah sosial dengan baik, yang pada akhirnya siswa yang belajar IPS dapat terbina menjadi warga negara yang baik dan bertanggung jawab. Makna dan hakikat belajar diartikan sebagai proses membangun pemahaman terhadap informasi dan/atau pengalaman. Proses itu disaring dengan persepsi, pikiran (pengetahuan awal), dan perasaan siswa (Sidi 2004: 4).

Pembelajaran IPS memiliki tugas mulia dan menjadi fondasi penting bagi pengembangan intelektual, emosional, kultural, dan sosial siswa, yaitu mampu menumbuh kembangkan cara berfikir, bersikap, dan berperilaku yang bertanggung jawab selaku individual, warga masyarakat, warga negara, dan warga dunia. Selain itu IPS pun bertugas mengembangkan potensi siswa agar peka terhadap masalah sosial yang terjadi di masyarakat, memiliki sikap mental positif untuk perbaikan segala ketimpangan, dan terampil mengatasi setiap masalah yang terjadi baik yang menimpa dirinya sendiri maupun yang di masyarakat. Tujuan tersebut dapat dicapai manakala programprogram pelajaran IPS di sekolah diorganisasikan secara baik.

Pola pembelajaran pendidikan IPS menekankan pada unsur pendidikan dan pembekalan pada siswa. Penekanan pembelajarannya bukan sebatas pada upaya memberikan siswa dengan sejumlah konsep yang bersifat hafalan belaka, melainkan terletak pada upaya agar mereka mampu menjadikan apa yang telah dipelajarinya sebagai bekal dalam memahami dan ikut serta dalam melakoni kehidupan masyarakat dan lingkungannya, serta sebagai bekal bagi dirinya untuk melanjutkan pendidikan ke jenjang yang lebih tinggi. Sumber utama proses 
pembelajaran IPS adalah aspek kehidupan sosial terkait dengan ruang tempat tinggalnya, apakah itu hubungan sosial, ekonomi, budaya, kejiwaan, sejarah, geografi ataukah politik, yang semuanya bersumber dari masyarakat. Hal ini sebagaimana dijelaskan oleh Winataputra (2007: 48) bahwa visi pendidikan IPS sebagai program pendidikan yang menitikberatkan pada pengembangan individu siswa sebagai "actor social" yang mampu mengambil keputusan yang bernalar dan sebagai "warga negara" yang cerdas, memiliki komitmen, bertanggung jawab dan partisipatif.

Kedudukan IPS dilihat dari segi fungsinya adalah untuk mengantarkan siswa menjadi warga negara yang aktif. Dalam hal ini, pembelajaran IPS memegang peranan yang penting karena harus mempersiapkan siswa untuk mengerti tentang peranannya, memahami hak dan kewajibannya, serta bertanggung jawab sebagai warga negara Inonesia. Peserta didik kita perlu ambil bagian secara aktif dalam kehidupannya, dia bukanlah warga negara yang pasif yang tidak memahami masalah di lingkungannya, dan bukan pula warga negara yang tidak mau tahu persoalan bangsanya, serta tidak mau terlibat dalam usaha memecahkan masalah tersebut.

Sumaatmadja (2007:

10)

menjelaskan tujuan pendidikan IPS adalah membina anak didik menjadi warga negara yang baik, yang memiliki pengetahuan, keterampilan dan kepedulian sosial yang berguna bagi dirinya sendiri serta bagi masyarakat dan negara. Untuk mewujudkan tujuan tersebut, proses pembelajaran dikelas tidak hanya terbatas pada aspek-aspek pengetahuan (kognitif), keterampilan (psikomotor) saja, tetapi harus terdapat ranah afektif yang meliputi setiap perilaku mental yang berhubungan dengan pemahaman, pertimbangan, pengolahan informasi, pemecahan masalah, kesengajaan, dan keyakinan (Trainin \& Swanson, 2005) Latifah (2010: 110). Ranah kognitif merupakan sumber sekaligus pengendali ranah-ranah lainnya yakni afektif dan psikomotorik. Melalui pendidikan IPS, peserta didik dibina dan dikembangkan kemampuan mentalintelektualnya menjadi warga negara yang berketerampilan dan berkepedulian sosial serta bertanggung jawab sesuai dengan nilai-nilai yang terkandung dalam Pancasila.

Kemampuan kognitif berperan penting pada proses pembelajaran siswa karena dengan kemampun ini memberikan siswa strategi belajar memahami isi materi pelajaran, strategi meyakini arti penting isi materi pelajaran, dan aplikasinya serta menyerap nilai-nilai yang terkandung dalam materi pelajaran tersebut (Love \& Kruger, 2005) Latifah (2010: 111). Dengan kata lain, jika kemampuan kognitif siswa baik maka kemungkinan besar menerima setiap materi dalam proses pembelajaran akan baik.

Tetapi kenyataan dalam proses pembelajaran baik di tingkat dasar maupun lanjutan, diperlukan ranah afektif sebagai menunjang keberhasilan ranah kognitif seorang siswa. Fakta empiris menunjukkan bahwa sekalipun kemampuan kognitif siswa tinggi tetapi ia tidak dapat mencapai prestasi akademik yang optimal, karena kegagalannya dalam meregulasi diri dalam belajar (Purwanto, 2000; Sunawan, 2002; Alsa, 2005) Latifah (2010: 112). Regulasi diri dalam belajar (self regulated learning) merupakan sebuah pendekatan yang penting. Strategi regulasi diri dalam belajar cocok untuk semua jenjang pendidikan, kecuali untuk kelas tiga SD ke bawah, ada yang menyarankan bahwa strategi belajar dengan regulasi diri kurang cocok (Woolfolk, 2008) Latifah (2010: 111). Lingkungan belajar siswa yang dominan mempengaruhi hasil belajar di sekolah ialah kualitas belajar mengajar. Sehingga untuk mencapai keberhasilan kualitas proses pembelajaran yang diharapkan perlu adanya suatu pendekatan yang relevan dengan tuntutan kurikulum yang terus berubah.

Siswa dengan regulari diri atau kemandirian yang baik akan cenderung 
lebih bisa memilih dan bertanggung jawab atas apa yang di berikan kepada dirinya. Kemandirian ini juga diharapkan muncul pada saat proses belajar, dimana siswa dengan inisiatif sendiri seharusnya dapat mengatur jam belajar sendiri, memilih kegiatan-kegiatan mana yang dapat menunjang prestasi akademiknya, menyusun strategi-strategi dalam belajar dan perilaku-perilaku lainnya yang menandakan bahwa siswa tersebut bertanggung jawab atas dirinya sendiri agar dapat berprestasi lebih baik. Kecenderungan siswa yang dengan kemanandirian dalam belajar yang baik berbanding lurus dengan kemampuan untuk mengatur dirinya. Siswa yang mengatur dirinya dengan baik akan mengontrol diri agar mendapatkan prestasi dalam belajar.

Kemampuan mengatur diri dalam proses belajar ini sering disebut dengan kemampuan Self Regulated Learning (SRL). SRL sendiri dalam bahasa Indonesia sering disebut dengan kemandirian belajar atau regulasi diri dalam pembelajaran. Konsep SelfRegulated Learning (SRL) dikemukakan pertama kali oleh Bandura dalam latar teori belajar sosial, bahwa setiap individu memiliki kemampuan mengontrol diri tentang cara belajarnya dengan mengembangkan langkah-langkah mengobservasi diri, menilai diri dan memberikan respon bagi dirinya sendiri. Zimmerman mengemukakan, dalam Schunk, dkk, (2012: 254) bahwa Selfregulation adalah proses dimana siswa mengaktifkan dan mempertahankan kognisi, perilaku, dan pengaruh yang sistematis berorientasi pada pencapaian tujuan mereka.

Salah satu komponen dalam self regulation, yaitu meregulasi usaha yang mempunyai hubungan dengan prestasi dan mengacu pada niat siswa untuk mendapatkan sumber, energi, dan waktu untuk dapat menyelesaikan tugas akademis yang penting (Wolters dkk., 2003: 24). Shunck 1996, Shunck dkk, (2008: 157) juga berpendapat bahwa siswa yang mengeksplorasi bagaimana tujuan dan evaluasi diri akan mempengaruhi hasil prestasinya. Schiefele dan Pekrun (dalam Baumert, dkk, 2002) mendefinisikan pengelolaan diri dalam belajar sebagai bentuk belajar individual dengan bergantung pada motivasi belajar mereka, secara otonomi (mandiri) mengembangkan pengukuran (kognisi, metakognisi dan perilaku) dan memonitor kemajuan belajarnya.

Kemandirian belajar penting untuk dimiliki oleh setiap siswa karena kemandirian belajar dapat menjadi salah satu faktor yang menentukan dalam keberhasilan belajar seorang siswa. Pentingnya kemandirian belajar didukung pula oleh hasil studi Hargis, Sumarmo (2004) dengan temuannya antara lain: individu yang memiliki kemandirian belajar yang tinggi cenderung belajar lebih baik, mampu memantau, mengevaluasi, dan mengatur belajarnya secara efektif, menghemat waktu dalam menyelesaikan tugasnya, mengatur belajar dan waktu secara efisien.

Dalam kegiatan pembelajaran, kemandirian sangat penting karena kemandirian merupakan sikap pribadi yang sangat diperlukan oleh setiap individu. Menurut Sumarmo (2006: 5) dengan kemandirian, siswa cenderung belajar lebih baik, mampu memantau, mengevaluasi, dan mengatur belajarnya secara efektif, menghemat waktu secara efisien, akan mampu mengarahkan dan mengendalikan diri sendiri dalam berfikir dan bertindak, serta tidak merasa bergantung pada orang lain secara emosional. Siswa yang mempunyai kemandirian belajar mampu menganalisis permasalahan yang kompleks, mampu bekerja secara individual maupun bekerjasama dengan kelompok, dan berani mengemukakan gagasan

Berdasarkan uraian di atas bahwa Self-Regulated Learning (SRL) merupakan suatu kegiatan belajar yang melibatkan aspek metakognisi, motivasi dan perilaku siswa dalam melaksanakan kegiatan belajar. Peserta didik yang melibatkan 
aspek-aspek metakognisi, motivasi dan perilaku dalam melaksanakan kegiatan belajarnya akan cenderung untuk menjadi otonom dalam melaksanakan kegiatan belajar. Keterlibatan aspek motivasi berupa pengarahan perilaku untuk mencapai kegiatan belajar. Mereka pada umumnya lebih bertanggung jawab terhadap kegiatan belajarnya karena mereka menyadari bahwa hanya atas usaha mereka sendirilah tujuan belajar mereka dapat dicapai.

Fakta yang terjadi di lapangan menunjukkan bahwa masih rendahnya Self Regulated Learning (SRL) siswa dalam proses belajar mengajar. Hal tersebut diperkuat berdasarkan pengalaman penulis selama mengajar di Sekolah Dasar Negeri Cingambul 5, dari hasil tiga kali ulangan harian pada semester I mata pelajaran IPS menunjukkan bahwa 7 siswa dari 26 siswa keseluruhan di ketahui mencontek kemudian di ketahui pula dari 26 siswa, 16 siswa baru belajar pada saat akan melaksanakan ujian. Ini menunjukan bahwa sebagian besar siswa tersebut belum memiliki kemampuan Self Regulated Learning (SRL) yang tinggi dan berdampak terhadap prestasi belajar mereka yang rendah.

$$
\text { Desmita (2009: }
$$

mengemukakan dalam konteks proses belajar mengajar, terlihat fenomena siswa yang kurang memiliki kemandirian dalam belajar, dapat menimbulkan gangguan mental setelah memasuki pendidikan lanjutan, kebiasaan belajar yang kurang baik (seperti tidak betah belajar lama atau belajar hanya menjelang ujian, membolos, dan menyontek). Kebiasan-kebiasan buruk tersebut jika dimiliki pada saat jenjang sekolah dasar akan terus berlanjut pada saat siswa tersebut melanjutkan pada sekolah menengah pertama, kemudian melajutkan ke sekolah menengah atas bahkan bisa terjadi pada saat melanjutkan di perguruan tinggi.

Berdasarkan penilitian pada tingkatan sekolah menengah pertama mengindikasikan Self-Regulated Learning (SRL) siswa rendah adalah melakukan kecurangan akademik seperti mencontek, sesuai dengan hasil penelitian Ashifa (2011) di SMPN 10 Bandung menyatakan bahwa terdapat hubungan antara SelfRegulated Learning (SRL) dengan perilaku mencontek. Seorang siswa yang memiliki Self-Regulated Learning (SRL) tinggi akan mempersiapkan diri dengan berbagai usaha dan strategi dalam belajar, maka kecenderungan melakukan kecurangan akademik akan rendah.

Penelitian selanjutnya pada tingkatan sekolah menengah atas yang dilakukan Widiyastuti (2012) diperoleh data tingkat Self-Regulated Learning (SRL) siswa kelas XI SMA Negeri 1 Nagreg tahu pelajaran 2011/2012 sebanyak $2,73 \%$ berada pada tingkat SRL tinggi, $15,45 \%$ tingkat SRL sedang, 46,36\% tingkat SRL rendah dan $35,45 \%$ tingkat SRL sangat rendah.

Rendahnya

Self-Regulated

Learning (SRL) di mulai dari pengalaman penulis di tingkat sekolah dasar dan penelitian yang telah dilakukan pada tingkat sekolah menengah pertama (SMP) kemudian penelitian pada sekolah menengah atas (SMA) ini mengindikasikan bahwa seorang siswa yang memiliki kemampuan Self-Regulated Learning (SRL) pada saat sekolah dasar (SD) rendah bisa berlanjut sampai pada tingkatan sekolah yang lebih tinggi.

Salah satu alternatif untuk mengembangkan kemampuan SelfRegulated Learning (SRL) siswa adalah dengan menggunakan pembelajaran yang memberikan tantangan kepada anak untuk belajar. Pembelajaran konvensional bersifat monolog dengan ceramah saja misalnya, akan sulit mendorong siswa untuk mengembangkan Self-Regulated Learning (SRL) dalam pembelajaran. Penerapan pembelajaran dengan memberikan pengalaman, mendorong siswa untuk memonitor kemampuan dirinya dalam membuat perencanaan dan pemantauan terhadap hasil belajar terkait tingkat penguasaan materi pembelajaran dan keberhasilan dalam menyelesaikan tugas -tugas secara baik. Kemauan belajar 
yang kuat dan penetapan tujuan belajar akan memacu setiap siswa rajin belajar dan berusaha mencapai tujuan dan target yang ditetapkan.

Kondisi saat ini di lapangan, metode pembelajaran yang digunakan oleh pendidik masih lekat dengan warna behavioristik, siswa sering diperlakukan seperti sebuah benda pasif yang tergantung pada elemen-elemen di luar dirinya.

Pengembangan materi ajar yang digunakan dalam buku ajar yang ada selama ini lebih terkonsentrasi pada pengembangan aspek psikomotoriknya saja, sementara aspek kognitif dan afektif masih terabaikan.

Selain itu, interaksi dalam proses belajar mengajar di sekolah dasar kerapkali bersifat monolog. Guru masih lebih banyak berperan sebagai perekayasa tingkah laku siswa, proses pembelajaran lebih berpusat pada guru, siswa lebih banyak dituntut untuk menyesuaikan semua aktivitasnya dengan lingkungan belajar yang ada, siswa lebih banyak melaksanakan aktivitas jasmani sesuai dengan instruksi guru, siswa kurang diberi kesempatan untuk mengembangkan kemandirian, tanggung jawab, dan motivasi dirinya.

Dengan begitu menyebabkan siswa menjadi malas mengikuti pelajaran serta tidak termotivasi untuk belajar. Sedangkan dalam pelaksanaannya, pendidikan jasmani di sekolah yang dilakukan oleh siswa harus dilakukan dengan motivasi tinggi, karena motivasi memegang peranan penting dalam kegiatan belajar.

Salah satu alternatif model pembelajaran yang bisa di gunakan adalah model pembelajaran kooperatif learning merupakan suatu model pengajaran dimana siswa belajar dalam kelompokkelompok kecil yang memiliki tingkat kemampuan berbeda (Depdiknas, 2004: 1), dimana yang diutamakan adalah kerjasama, yakni kerjasama antar siswa dalam kelompok untuk mencapai tujuan pembelajaran.

Model pembelajaran tipe Think Pair and Share (TPS) dikembangkan oleh
Frank Lyman dkk dari Universitas Maryland. Model pembelajaran ini memberikan banyak waktu kepada setiap siswa untuk berpikir, merespon, dan saling membantu antara yang satu dengan yang lain. Pada kelompok kecil setiap siswa perlu dipupuk suasana yang saling membantu, saling menghargai dan bukan suasana persaingan. Setiap siswa harus diberi pengertian bahwa orang yang memberi ilmu justru akan lebih memperkaya pengetahuannya. Ini artinya dengan memberi penjelasan tentang hasil diskusi kepada temannya ia akan lebih menguasai materi tersebut.

Model Think Pair Share (TPS) merupakan jenis pembelajaran kooperatif yang dirancang untuk mempengaruhi pola interaksi siswa (Trianto, 2012: 61). Model Think Pair Share (TPS) ini berkembang dari penelitian belajar kooperatif dan waktu tunggu. Dengan asumsi bahwa semua resitasi atau diskusi membutuhkan pengaturan untuk mengendalikan kelas secara keseluruhan, dan prosedur yang digunakan dalam Think Pair Share (TPS) dapat memberi waktu lebih banyak siswa untuk berpikir, untuk merespon dan saling membantu. Arends (dalam Trianto 2011: 61) menyatakan bahwa Think Pair Share (TPS) merupakan satu cara yang efektif untuk membuat variasi suasana pola diskusi kelas.

Pendapat Lyman dalam Nurhadi (2005: 120), Think Pair Share (TPS) merupakan metode pembelajaran yang dapat mengaktifkan seluruh siswa selama proses pembelajaran dan memberikan kesempatan untuk bekeja sama antar siswa yang mempunyai kemampuan heterogen. Dikemukakan oleh Lie (2002: 56) bahwa, Think Pair Share (TPS) adalah pembelajaran yang memberi siswa kesempatan untuk bekerja sendiri dan bekerjasama dengan orang lain. Think Pair Share (TPS) memiliki prosedur secara eksplisit dapat memberi siswa waktu lebih banyak untuk berpikir, menjawab, saling membantu satu sama lain (Ibrahim, 2007: 10) dengan cara ini diharapkan siswa mampu bekerja sama, saling 
membutuhkan dan saling bergantung pada kelompok-kelompok kecil secara kooperatif.

Think Pair and Share (TPS) memberikan kesempatan kepada siswa untuk bekerja sendiri dan bekerja sama dengan orang lain. Keunggulan lain dari pembelajaran ini adalah optimalisasi partisipasi siswa pada saat proses pembelajaran. Dengan metode klasikal memungkinkan hanya satu peserta didik maju dan membagikan hasilnya untuk seluruh kelas, tapi pembelajaran ini memberi kesempatan sedikitnya delapan kali lebih banyak kepada peserta didik untuk dikenali dan menunjukkan partisipasi mereka kepada orang, Lie (2002: 57).

Model pembelajaran kooperatif tipe Think Pair Share (TPS) merupakan salah satu model pembelajaran kooperatif yang mampu mengubah asumsi bahwa metode resitasi dan diskusi perlu diselenggarakan dalam setting kelompok secara keseluruhan. Karakteristik model Think Pair Share (TPS) siswa dibimbing secara mandiri, berpasangan, dan saling berbagi untuk menyelesaikan permasalahan.

Model ini selain diharapkan dapat menjembatani dan mengarahkan proses belajar mengajar juga mempunyai dampak lain yang sangat bermanfaat bagi siswa. Model pembelajaran ini menuntut siswa untuk mendengarkan, berfikir, serta mengutarakan hasil pemikiran mereka tentang ide-ide pelajaran yang telah mereka temukan. Hal ini mengindikasikan siswa harus sadar untuk terlibat dalam pembelajaran sehingga Self-Regulated Learning (SRL) siswa pada pembelajaran IPS semakin meningkat dengan mempergunakan pembelajaran model ini.

\section{Metode Penelitian}

1) Desain Penelitian

Penelitian ini merupakan penelitian quasi experiment atau eksperimen semu yang terdiri dari dua kelompok penelitian yaitu kelas eksperimen (kelas perlakuan) kelompok siswa yang pembelajarannya menggunakan pembelajaran kooperatif tipe Think Pair Share (TPS) dan kelompok kontrol (kelas pembanding) adalah kelompok siswa yang pembelajarannya menggunakan pembelajaran konvensional. Desain penelitian ini digunakan karena kelas sudah terbentuk sebelumnya, sehingga tidak dilakukan lagi pengelompokkan secara acak. Apabila dilakukan pembentukan kelas baru memiliki potensi kekacauan jadwal pelajaran dan mengganggu efektivitas pembelajaran yang sedang berjalan.

Dengan demikian untuk mengetahui adanya perbedaan peningkatan kemampuan Self-Regulated Learning (SRL) dilakukan penelitian dengan desain kelompok Non-Equivalent Control Group Design (Sugiyono 2009: 116) berikut:

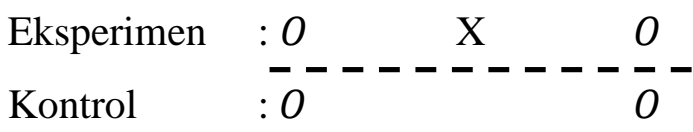

Keterangan:

$\mathrm{O} \quad=$ Pretes dan Postes

$X \quad=$ Model Kooperatif TPS

- - - = Subjek tidak dikelompokkan secara acak

Pada desain di atas, kedua kelompok diberikan pretes terlebih dahulu sebelum diberikan perlakuan. Setelah diberi perlakuan, kedua kelompok diberikan kembali postes untuk pengukuran. Tujuan diberikannya pretes adalah untuk melihat kemampuan awal kedua kelompok. Penelitian ini melibatkan variabel bebas dan variabel terikat. Variabel bebas adalah pembelajaran dengan menggunakan model pembelajaran kooperatif tipe Think Pair Share (TPS), sedangkan variabel terikatnya adalah kemampuan Self-Regulated Learning (SRL).

2) Populasi dan Sampel Penelitian

Populasi dalam penelitian ini adalah seluruh siswa kelas IV SD di UPTD Kecamatan Cingambul Kabupaten Majalengka Provinsi Jawa Barat. Pengambilan sampel dilakukan secara Purposive Sampling, yakni dua kelas dari 
jumlah seluruh kelas yang ada. Satu kelas dijadikan sebagai kelas eksperimen yang memperoleh pembelajaran menggunakan model pembelajaran kooperatif tipe Think Pair Share (TPS), dan satu kelas lainnya sebagai kelas kontrol yang memperoleh pembelajaran konvensional.

3) Instrumen Penelitian

Skala psikologi self regulated learning (SRL) dalam penelitian ini dimaksudkan untuk mengungkap seberapa tinggi usaha siswa yang dilakukan secara sistematis untuk memfokuskan pikiran, perasaan, dan perilaku pada pencapaian tujuan pembelajaran. Dalam skala psikologi ini menggunakan empat alternatif jawaban, antara lain : STS (Sangat Tidak Setuju), TS (Tidak Setuju), S (Setuju), SS (Sangat Setuju). Sedangkan jenis pertanyaan atau pernyataan terdiri dari dua jenis antara lain: favorable dan unfavorable. Skor item yang digunakan adalah 1, 2, 3, 4. Pemberian skor untuk pertanyaan favorable, untuk jawaban STS diberi skor 1, jawaban TS diberi skor 2, jawaban S diberi skor 3, dan jawaban SS diberi skor 4. Begitu juga sebaliknya untuk pertanyaan unfavorable jawaban STS diberi skor 4, jawaban TS diberi skor 3, jawaban $\mathrm{S}$ diberi skor 2, dan jawaban SS diberi skor 1.

Skala psikologi yang digunakan dalam penelitian ini memiliki empat alternatif jawaban, tanpa menggunakan jawaban netral. Pemilihan empat alternatif jawaban tanpa jawaban netral tersebut berdasarkan pada pertimbangan sebagai berikut menurut Hadi dalam (Puspitasari 2013: 56-57) :

a. Kategori undecided itu mempunyai arti ganda, bisa diartikan belum dapat memutuskan atau memberi jawaban (menurut konsep aslinya), bisa juga diartikan netral, setuju tidak, tidak setujupun tidak, atau bahkan raguragu

b. Adanya pilihan tengah atau netral membuat responden menjadi raguragu c. Maksud kategorisasi jawaban SS-STS-STS adalah terutama untuk melihat kecenderungan pendapat responden, ke arah setuju atau ke arah tidak setuju.

Aspek-aspek yang digunakan dalam skala self regulated learning (SRL) siswa adalah (1) personal function, (2) behavior function, (3) environmental function yang diturunkan menjadi beberapa indikator rehearsing \& memorizing (siswa berusaha untuk berlatih dan menghapalkan), goal setting \& planning (penetapan tujuan belajar serta merencanakan urutan, waktu, dan penyelesaian aktivitas-aktivitas yang berhubungan dengan tujuan), selfevaluating (siswa melakukan evaluasi terhadap kualitas atau kemajuan dari pekerjaanya), self-consequenting (siswa membayangkan reward dan punishment yang didapat jika memperoleh kesuksesan atau kegagalan), seeking information (siswa berusaha untuk mencari informasi lebih lengkap dari sumber-sumber nonsosial), keeping records \& selfmonitoring (siswa berusaha untuk mencatat berbagai kejadian atau hasil yang diperoleh dalam proses belajar), environmental structuring (siswa berusaha untuk memilih atau mengatur lingkungan fisik sehingga proses belajar menjadi lebih mudah), dan seeking social assistance (siswa berusaha mencari bantuan dari teman sebaya, guru, orang dewasa lainnya yang dianggap bisa membantu).

\section{Hasil Penelitian dan Pembahasan}

Analisis data awal dilakukan untuk mengetahui apakah self-regulated learning siswa sebelum diberi perlakuan sama atau berbeda secara signifikan. Analisis data awal yang dilakukan adalah uji perbedaan rerata preskala self-regulated learning. Untuk memilih jenis uji perbedaan rerata yang akan dipakai, terlebih dahulu dilakukan uji prasyarat. Uji prasyarat yang dimaksud adalah uji normalitas data dan uji homogenitas varians. Uji normalitas data menggunakan uji KolmogorovSmirnov $^{a}$ sedangkan untuk uji 
homogenitas varians menggunakan uji Levene.

Jika kedua data berasal dari populasi yang berdistribusi normal dan homogen, maka uji perbedaan rerata menggunakan uji-t. Jika kedua data berasal dari populasi yang berdistribusi normal akan tetapi tidak homogen, maka uji perbedaan rerata menggunakan uji-t'. sedangkan jika salah satu atau kedua data berasal dari populasi yang tidak berdistribusi normal, maka uji perbedaan rerata adalah uji Mann-Whitney.

\section{1) Analisis Data Pretes}

\section{Uji Normalitas}

Dalam melakukan uji normalitas, penulis menggunakan bantuansoftware SPSS 20 dengan Uji Kolmogorov-Smirnov pada taraf signifikansi $\alpha=0,05$. Uji normalitas dilakukan menggunakan uji Kolmogorov-Smirnov ${ }^{a}$. Hasil perhitungan uji normalitas disajikan pada Tabel di bawah ini :

Tabel 1

Data Hasil Uji Normalitas Rerata Preskala Self-Regulated Learning (SRL)

\begin{tabular}{|c|l|c|c|c|l|}
\hline \multirow{2}{*}{ Pembelajaran } & \multicolumn{3}{|c|}{ Kolmogorov-Smirnov ${ }^{a}$} & \multirow{2}{*}{ Kesimpulan } \\
\cline { 3 - 5 } \multicolumn{2}{|c|}{} & $\mathrm{N}$ & Sig. & Ket. & \\
\hline \multirow{2}{*}{ Preskala } & Eksp. & 24 & 0,200 & $\mathrm{H}_{\mathrm{o}}$ Diterima Normal \\
\cline { 2 - 5 } & Kon. & 24 & 0,200 & $\mathrm{H}_{\mathrm{o}}$ Diterima Normal \\
\hline
\end{tabular}

$\mathrm{H}_{\mathrm{o}}$ : data sampel berasal dari populasi berdistribusi normal

Berdasarkan tabel di atas menunjukkan bahwa nilai signifikansi untuk preskala kelas pembelajaran kooperatif tipe Think Pair Share 0,200 dan kelas konvensional sebesar 0,200. Nilai signifikansi untuk kedua kelas lebih besar dari $\alpha=0,05$ maka $\mathrm{H}_{\mathrm{o}}$ diterima. Artinya, data nilai preskala untuk kelas pembelajaran kooperatif tipe think pair share maupun kelas konvensional berasal dari populasi yang berdistribusi normal.

\section{Uji Homogenitas Varians}

Karena data pretes self-regulated learning siswa untuk kedua kelas berasal dari populasi yang berdistribusi normal, maka dilanjutkan dengan melakukan uji homogenitas varians dari kedua kelas eksperimen dan kontrol.

Tabel 2

Data Hasil Uji Homogenitas Rerata

Preskala Self-Regulated Learning (SRL)

\begin{tabular}{|l|l|c|c|}
\hline \multirow{2}{*}{ Kelas } & \multicolumn{2}{|c|}{ Uji Levene } & \multirow{2}{*}{ Kesimpulan } \\
\cline { 2 - 3 } & Sig. & Ket. & \\
\hline Eksp. & 0,394 & $\begin{array}{c}\mathrm{H}_{\mathrm{o}} \\
\text { Diterima }\end{array}$ & \multirow{2}{*}{ Homogen } \\
\hline Kon. & & \\
\hline
\end{tabular}

$\mathrm{H}_{\mathrm{o}}: \sigma_{1}^{2}=\sigma_{2}^{2}$

Berdasarkan tabel 2 di atas menunjukkan bahwa nilai signifikansi uji homogenitas varians dari data pretes selfregulated learning adalah 0,394. Nilai signifikansi ini lebih besar dari $\alpha=0,05$, sehingga $\mathrm{H}_{\mathrm{o}}$ diterima. Dengan demikian dapat disimpulkan bahwa varians dari kedua kelompok adalah homogen.

\section{Uji Perbedaan Rerata Skor Preskala}

Hasil uji prasyarat, yaitu uji normalitas dan uji homogenitas menunjukkan bahwa data preskalas selfregulated learning untuk kelas kooperatif tipe Think Pair Share dan kelas konvensional berasal dari populasi yang berdistribusi normal dan bervarians homogen. Oleh karena itu uji hipotesis perbedaan self-regulated learning awal siswa dilakukan dengan menggunakan ujit. Hasil perhitungan uji perbedaan rerata disajikan pada tabel berikut:

Tabel 3

Data Hasil Uji Perbedaan Rerata Skor

Preskala Self-Regulated Learning (SRL)

\begin{tabular}{|c|c|c|c|}
\hline Kelas & $\begin{array}{c}\text { Sig. } \\
\text { Independent } \\
\text { T-test }\end{array}$ & Ket. & Kesimpulan \\
\cline { 1 - 1 } Eksp. & 0,235 & $\begin{array}{c}\mathrm{H}_{\mathrm{o}} \\
\text { Diterima }\end{array}$ & $\begin{array}{c}\text { Tidak Terdapat } \\
\text { Perbedaan }\end{array}$ \\
\cline { 1 - 1 } Kon. & \multirow{2}{*}{}
\end{tabular}

$H_{o}: \mu_{1}=\mu_{2}$

Tabel di atas menunjukkan nilai signifikansi uji-t dari data pretes selfregulated learning adalah 0,235. Nilai signifikansi ini lebih besar dari 0,05, maka $\mathrm{H}_{\mathrm{o}}$ diterima. Artinya, tidak terdapat perbedaan yang signifikan antara selfregulated learning awal siswa yang pembelajarannya menggunakan 
pemebalajaran kooperatif tipe Think Pair Share dengan siswa yang pembelajarannya menggunakan pembelajaran konvensional.

\section{2) Analisis Data N-gain}

Analisis data N-gain dilakukan untuk melihat perbedaan peningkatan selfregulated learning siswa yang pembelajarannya menggunakan pembelajaran Kooperatif Tipe Think Pair Share dengan siswa yang pembelajarannya menggunakan pembelajaran konvensional. Analisis data $\mathrm{N}$-gain dilakukan dengan uji perbedaan rerata. Untuk memilih jenis uji perbedaan rerata yang akan dipakai, terlebih dahulu dilakukan uji prasyarat. Uji prasyarat yang dimaksud adalah uji normalitas data dan uji homogenitas varians. Uji normalitas data menggunakan Kolmogorov-Smirnov ${ }^{a}$ sedangkan untuk uji homogenitas varians menggunakan uji Levene.

\section{Uji Normalitas}

Uji normalitas dilakukan menggunakan uji Kolmogorov-Smirnov ${ }^{a}$. Hasil perhitungan uji normalitas disajikan pada Tabel berikut.

\section{Tabel 4}

Data Hasil Uji Normalitas Rerata N-gain Self-Regulated Learning (SRL)

\begin{tabular}{|c|l|c|c|c|c|}
\hline \multirow{2}{*}{ Pembelajaran } & \multicolumn{3}{|c|}{ Kolmogorov-Smirnov $^{a}$} & \multirow{2}{*}{ Kesimpulan } \\
\cline { 3 - 6 } \multicolumn{2}{|c|}{} & $\mathrm{N}$ & Sig. & Ket. & \\
\hline \multirow{2}{*}{ N-gain } & Eksp. & 24 & 0,054 & $\mathrm{H}_{\mathrm{o}}$ Diterima & Normal \\
\cline { 2 - 5 } & Kon. & 24 & 0,063 & $\mathrm{H}_{\mathrm{o}}$ Diterima Normal \\
\hline
\end{tabular}

$\mathrm{H}_{\mathrm{o}}$ : data sampel berasal dari populasi berdistribusi normal

Tabel di atas menunjukkan nilai signifikansi untuk data $\mathrm{N}$-gain selfregulated learnings kelas yang yang menggunakan pembelajaran dengan kooperatif Tipe Think Pair Share sebesar 0,054, lebih besar $\alpha=0,05$ maka $\mathrm{H}_{\mathrm{o}}$ diterima. Kemudian nilai signifikansi kelas yang menggunakan pembelajaran konvensional sebesar 0,063, lebih besar dari $\alpha=0,05$ maka $\mathrm{H}_{\mathrm{o}}$ diterima. Artinya, data N-gain self-regulated learning untuk kedua kelas berasal dari populasi yang berdistribusi normal.

\section{Uji Homogenitas Varians}

Karena data N-Gain self-regulated learning siswa untuk kedua kelas berasal dari populasi yang berdistribusi normal, selanjutnya dilakukan uji homogenitas varians dari kedua kelas. Berikut ini disajikan hasil dari perhitungan uji homogenitas:

Tabel 5

Data Hasil Uji Homogenitas N-Gain SelfRegulated Learning (SRL)

\begin{tabular}{|l|l|c|c|}
\hline \multirow{2}{*}{ Kelas } & \multicolumn{2}{|c|}{ Uji Levene } & \multirow{2}{*}{ Kesimpulan } \\
\cline { 2 - 3 } & Sig. & Ket. & \\
\hline Eksp. & 0,040 & $\begin{array}{c}\mathrm{H}_{\mathrm{o}} \\
\text { Ditolak }\end{array}$ & $\begin{array}{c}\text { Tidak } \\
\text { Homogen }\end{array}$ \\
\hline Kon. & \multirow{2}{*}{} \\
\hline
\end{tabular}

$\mathrm{H}_{\mathrm{o}}: \sigma_{1}^{2}=\sigma_{2}^{2}$

Berdasarkan tabel di atas menunjukkan bahwa nilai signifikansi uji homogenitas varians dari data preskala self-regulated learning adalah 0,04. Nilai signifikansi ini lebih besar dari $\alpha=0,05$, sehingga $\mathrm{H}_{\mathrm{o}}$ ditolak. Dapat disimpulkan varians kedua kelompok tidak homogen.

\section{Uji Perbedaan Rerata Data N-gain}

Hasil uji prasyarat, yaitu uji normalitas dan uji homogenitas menunjukkan bahwa data N-gain selfregulated learning kelas dengan pembelajaran kooperatif tipe Think Pair Share dan kelas konvensional berasal dari populasi yang berdistribusi normal. Sedangkan berdasarkan hasil uji homogenitas kedua kelas tersebut menunjukan bahwa varians dari kedua kelas tidak homogen, oleh karena itu uji hipotesis perbedaan $\mathrm{N}$-gain self-regulated learning siswa dilakukan dengan menggunakan uji-t'.

Hipotesis penelitian yang diajukan, yaitu:

"Peningkatan kemampuan Self-Regulated Learning (SRL) siswa yang dalam pembelajarannya menggunakan pembelajaran kooperatif tipe Think Pair Share (TPS) lebih baik daripada siswa yang menggunakan pembelajaran konvensional". 
Rumusan hipotesis statistik yang diuji untuk menguji hipotesis yang diajukan:

$$
\begin{aligned}
& H_{o}: \mu_{1}=\mu_{2} \\
& H_{a}: \mu_{1}>\mu_{2}
\end{aligned}
$$

Keterangan:

$\mu_{1}$ : Rerata skor N-gain self-regulated learning siswa yang pembelajarannya menggunakan pembelajaran kooperatif tipe Think Pair Share (kelas eksperimen)

$\mu_{2}$ : Rerata skor N-gain self-regulated learning siswa yang pembelajarannya menggunakan pembelajaran konvensional (kelas konvensional)

Signifikansi yang dihasilkan uji-t' adalah sig. (2-pihak). Sedangkan uji-t' yang digunakan untuk menguji perbedaan rerata gain self-regulated learning adalah uji satu pihak. Menurut Uyanto (2009), nilai sig. (1-pihak) $=\frac{1}{2} \times$ sig. (2-pihak). Oleh karena itu, kriteria pengujian yang digunakan adalah jika sig. (1-pihak) lebih besar dari $\alpha=0,05$ maka $\mathrm{H}_{\mathrm{o}}$ diterima, untuk kondisi lainnya $\mathrm{H}_{\mathrm{o}}$ ditolak. Hasil perhitungan uji perbedaan rerata disajikan pada tabel 6.

Tabel 6

Data Hasil Uji Perbedaan Rerata Data Ngain Self-Regulated Learning (SRL)

\begin{tabular}{|c|c|c|c|}
\hline Kelas & $\begin{array}{c}\text { Sig. } \\
\text { Mann-Whitney } \\
\text { (1-pihak })\end{array}$ & Ket. & Kesimpulan \\
\hline Eksp. & 0,000 & $\begin{array}{c}\mathrm{H}_{\mathrm{o}} \\
\text { ditolak }\end{array}$ & $\begin{array}{c}\mathrm{H}_{a} \\
\text { Diterima }\end{array}$ \\
\hline Kon. & \multicolumn{2}{c}{} \\
\hline
\end{tabular}

$H_{o}: \mu_{1}=\mu_{2}$

Tabel di atas menunjukkan nilai sig. (1-pihak) sebesar 0,000 artinya nilai signifikansi ini lebih kecil dari 0,05, maka dapat disimpulkan $\mathrm{H}_{\mathrm{o}}$ ditolak. Artinya, peningkatan self-regulated learning siswa yang memperoleh pembelajaran menggunakan pembelajaran kooperatif tipe Think Pair Share secara signifikan lebih baik daripada siswa yang memperoleh pembelajaran konvensional.

Pembelajaran kooperatif tipe Think Pair Share mengharuskan siswa untuk bekerja baik itu secara mandiri ataupun secara berkelompok. Hal ini menyebabkan siswa harus memiliki kesadaran kapan harus bekerja secara mandiri, kapan harus berdiskusi dalam kelompok dan dapat mengeluarkan pendapat. Pembelajaran kooperatif tipe Think Pair Share juga mengharuskan siswa mengeluarkan pendapat secara bergiliran tanpa adanya interupsi berupa pertanyaan atau tanggapan dari anggota kelompok lain. Dalam sesi ini, siswa harus sadar akan kesempatan setiap orang untuk mengeluarkan pendapatnya. Selain itu, siswa menjadi sadar akan kebutuhannya terhadap pembelajaran IPS. Seperti yang dikemukakan Clowes (2010) bahwa ketika siswa berinteraksi dengan orang lain, mereka belajar keterampilan sosial, kerakter dan kecerdasan emosional. Salah satu aspek dari kecerdasan emosional adalah self-regulated learning. Oleh karena itu, tahapan-tahapan yang dilakukan dalam pembelajaran kooperatif tipe Think Pair Share melatih selfregulated learning siswa.

Berbeda dengan kegiatan pembelajaran pada kelas yang menggunakan pembelajaran konvensional, siswa hanya duduk mendengarkan penjelasan dari guru. Self-regulated learning kurang terlatih, karena siswa pasif dalam pembelajaran dan tidak dituntut untuk mengeluarkan pendapat baik itu di dalam diskusi kelompok ataupun dalam diskusi kelas.

\section{Kesimpulan}

Peningkatan kemampuan selfregulated learnings siswa yang memperoleh pembelajaran kooperatif tipe Think Pair Share lebih baik daripada siswa yang memperoleh pembelajaran konvensional. Peningkatan pada pada kelas dengan pembelajaran kooperatif tipe Think Pair Share termasuk kategori sedang sedangkan untuk kelas dengan 
pembelajaran konvesional mendapatkan katergori rendah.

\section{Daftar Pustaka}

Alhaddad, I. (2014). Peningkatan kemampuan komunikasi dan pemecahan masalah matematis serta self-regulatedlearning mahasiswa melalui pembelajaran model treffinger. Skripsi (Online). Tidak dipublikasikan, UPI Bandung

Ashifa. (2011). Pengaruh Strategi Self Regulated Learning dengan PerilakuMencontek Pada Siswa Kelas VII SMPN 10 Bandung. Skripsi (online). Tidak Dipublikasikan UPI Bandung.

Arikunto, S. (2010). Prosedur Penelitian Suatu Pendekatan Praktik. Jakarta : PT Rineka Cipta.

Baumert et al., (2002). Self Regulated L earning as Cross Cultural Conce pt. Diakses dari http://www.mpibberlin.mpg.de/ pisa/pdfs/ccengl.pdf

Deasyanti. Armei, Anna. (2007). Self Regulation Leraning pada Mahasiswa Fakultas Pendidikan Universitas Negeri Jakarta. Perspektif Ilmu Pendidikan. VOL. 16, Th.VIII

Desmita. (2010). Psikologi Perkembangan Peserta Didik; Panduan bagi Orang Tua dan Guru dalam Memahami Psikologi Anak Usia SD, SMP, dan SMA. Bandung: Remaja Rosdakarya.

Depdiknas. 2006. Peraturan Menteri Pendidikan Nasional Nomor 22 Tahun 2006. Tentang Standar Isi

Depdiknas. (2008). Jurnal Pendidikan dan Kebudayaan. Jakarta: Balitbang Depdiknas.
Depdiknas Undang-undang SISDIKNAS 2003 (UU RI No. 20 Th.2003). 2005. Solo: Kharisma.

Hake, R. (1999).Analyzing Change/Gain Scores.Area-D-American

Educational Research Association's Division D, Measurement and Research Methology. [Online]. Tersedia www. Physic.indiana.edu/sdi/AnalyzingChangeGain.pdf

Huda, M. (2011) Cooperative Learning Metode, Teknik Struktur dan Model Penerapan.Yogyakarta: Pustaka Pelajar.

Ibrahim. 2007. Penelitian dan Penilaian Pendidikan. Bandung : Sinar Baru Algensindo.

Lie, Anita. 2002. "Cooperative Learning : Mempraktikan Cooperative Learning di Ruang-ruang Kelas". Jakarta : PT. Gramedia.

Latipah, Eva, (2010). Strategi SelfRegulated Learning dan Prestasi Belajar: Kajian Meta Analisis Jurnal Psikologi Pendidikan Volume 37, No. 1, Juni 2010: 110129

Ormrod, J. E. (2008). Psikologi Pendidikan. Jakarta: Erlangga

Nurhadi, S. (2003). Pembelajaran Kontekstual (Contextual

Teachingand Learning/CTL) dan Penerapannya dalam KBK. Malang: Universitas Negeri Malang (UMPRESS).

Nurhadi. 2005. Membaca Cepat dan Efektif. Bandung: Sinar baru Algensindo.

Pujiati, I. N. (2010). Hubungan Antara Efikasi Diri Dengan Kemandirian Belajar Siswa : Studi Terhadap Siswa Kelas VII SMP Negeri 2 Rajapolah Kabupaten Tasikmalaya 
Tahun Ajaran 2010/2011. Skripsi (online). Bandung : UPI.

Schunk. H.D, Pintrich, P. R, dan Mecce. L.J. (2008). Motivational In Education:theory, research, and application. Ohio : Pearson Press.

Schunk, H.D. (2012). Learning Theories: An educational perspective (6th Ed).Translated by Hamdiah, E dan Rahmat, F. Yogyakarta: Pustaka Pelajar.

Sidi, Indra, J.(2004) Pelayanan Profesional, Kegiatan BelajarMengajar yang Efektif. Jakarta: Puskur Balitbang Depdiknas

Slavin, R. E. (2006). Educational Psycologi : Theory and Pratice. London: Pearson Education

Slavin, R. E. ( 2008) Cooperative Learning : Teori, Riset dan Praktik. Bandung: Nusa Media

Subana. ( 2005). Dasar-dasar Penelitian Ilmiah. Bandung: CV.Pustaka Setia.

Sugiyono. (2009). Metode Penelitian Kuantitatif dan Kualitatif. CV.Alfabeta: Bandung.

Suherman, E. dkk.(2001). Strategi Pembelajaran Matematika Kontemporer. Bandung: UPI

Suherman, E. dkk.(2003). Evaluasi Pembealajaran Matematika. Individual Textbook. Bandung: Jurusan FMIPA UPI Bandung

Summaatmadja, N.(2007). Konsep Dasar IPS. Jakarta: Universitas Terbuka

Sumarmo, U. (2004). Kemandirian Belajar: Apa, Mengapa dan Bagaimana Dikembangkan pada Peserta Didik. Makalah disajikan pada Seminar Pendidikan Matematika di Jurusan Pendidikan Matematika FMIPA Universitas
Negeri Yogyakarta, tanggal 8 Juli 2004. Tidak dipublikasikan.

Sumarmo, U. (2005). Pembelajaran Matematika untuk Mendukung Pelaksanaan Kurikulum Tahun 2002 Sekolah Menengah. Disajikan dalam Seminar Pendidikan Matematika. UPI: Tidak diterbitkan.

Suprijono, A.(2009). Cooperative Learning Teori dan Aplikasi PAIKEM. Yogyakarta Pustaka Pelajar

Trianto. (2009). Medesain Model Pemebelajaran Inovatif-Progresif. Jakarta: Kencana

Tresnawati, Nina (2013) Pembelajaran Generatif Untuk Meningkatkan Kemampuan Koneksi Matematis Dan Kemandirian Belajar Matematika Mahasiswa. S2 thesis, Universitas Pendidikan Indonesia. Tidak dipublikasikan

Widiyastuti, H. (2012). Program Bimbingan Belajar Melalui Strategi Metakognitif Untuk Meningkatkan Self Regulated Learning Siswa SMA Negeri 1 Nagreg. Tesis (online). Bandung : UPI

Winataputra, Udin, dkk.(2007). Teori Belajar dan Pembelajaran. Jakarta: Universitas Terbuka

Wolters, Christopher A. 1998. Selfregulated learning and college students' regulation of motivation. Journal of Educational Psychology. Vol. 90, No. 2 : 224235. 